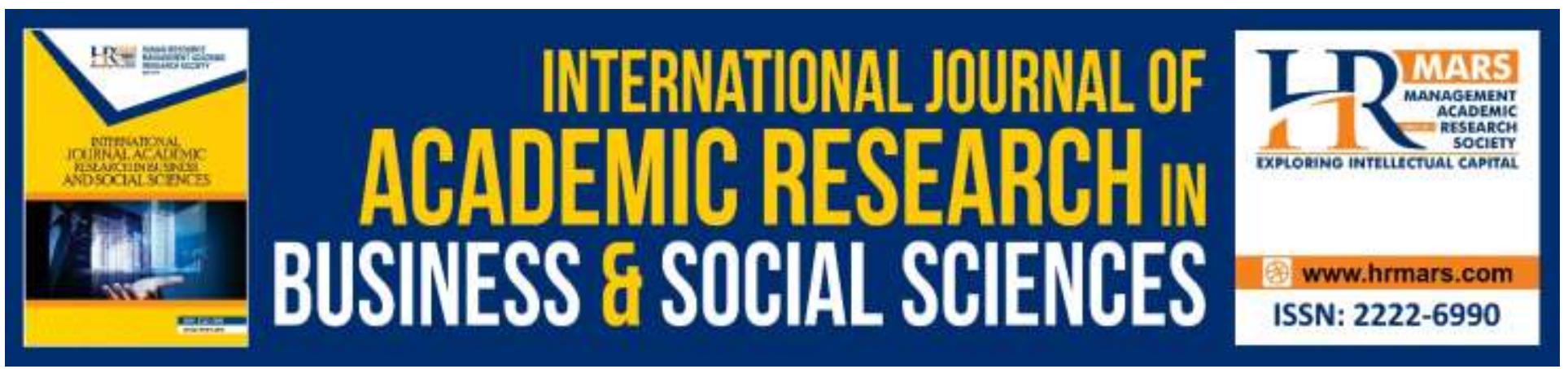

\title{
Twin Deficits and Debts in 6 ASEAN Countries: A Panel Approach
}

\author{
Soo Xin Lin \& Jerome Kueh
}

To Link this Article: http://dx.doi.org/10.6007/IJARBSS/v9-i7/6147

DOI: $10.6007 /$ IJARBSS/v9-i7/6147

Received: 13 May 2019, Revised: 19 June 2019, Accepted: 30 June 2019

Published Online: 24 July 2019

In-Text Citation: (Lin \& Kueh, 2019)

To Cite this Article: Lin, S. X., \& Kueh, J. (2019). Twin Deficits and Debts in 6 ASEAN Countries: A Panel Approach. International Journal of Academic Research in Business and Social Sciences, 9(7), 550-559.

Copyright: (C) 2019 The Author(s)

Published by Human Resource Management Academic Research Society (www.hrmars.com)

This article is published under the Creative Commons Attribution (CC BY 4.0) license. Anyone may reproduce, distribute, translate and create derivative works of this article (for both commercial and non-commercial purposes), subject to full attribution to the original publication and authors. The full terms of this license may be seen at: http://creativecommons.org/licences/by/4.0/legalcode

Vol. 9, No. 7, 2019, Pg. 550 - 559

http://hrmars.com/index.php/pages/detail/IJARBSS

JOURNAL HOMEPAGE

Full Terms \& Conditions of access and use can be found at http://hrmars.com/index.php/pages/detail/publication-ethics 


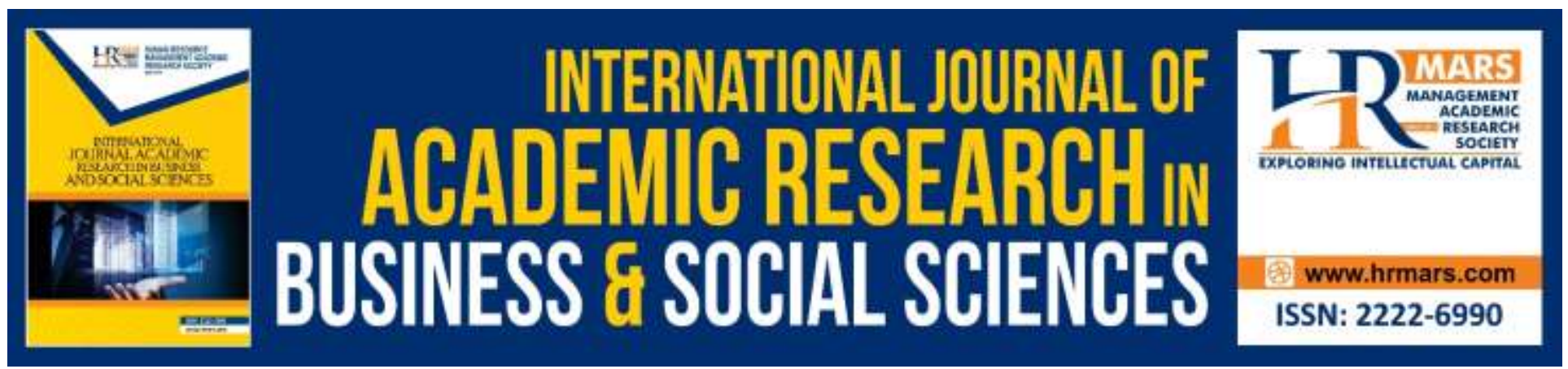

\title{
Twin Deficits and Debts in 6 ASEAN Countries: A Panel Approach
}

\author{
Soo Xin Lin \& Jerome Kueh
}

Faculty of Economics and Business, Universiti Malaysia Sarawak, 94300 Kota Samarahan, Sarawak, Malaysia

\begin{abstract}
In order to maintain the macroeconomic stability and sustainable economic growth, the current account deficit and fiscal deficit must be controlled. Besides, a country may encounter deficits that result in accumulation of debt during economic shock. This study aims to examine relationship between twin deficits and debts. The sample period is from 1990 to 2016 annually for 6 ASEAN countries. The methodology is pooled mean group (PMG) estimation. The finding shows that current account balance $(C A B)$ and fiscal balance $(F B)$ have positive significant relationship with the presence of debts.
\end{abstract}

Keywords: Twin Deficits, Debts, Current Account Balance, Fiscal Balance

\section{Introduction}

According to Baharumshah, Ismail, and Lau (2009), the relation among FB and CAB is often a subject of analysis. $C A B$ is a major guiding of economic health that concluded as the total of trade balances, net current transfers and net foreign income. However, FB is a financial statement presenting government's revenues and spending. When fiscal account and CA that having deficit are being pull together, they are so called twin or double deficit. Fiscal deficit describes situation where country's expenses overtake revenues; whereas, CA deficit takes place when a nation imports exceed exports. The consistency behind these double deficits is that government reduces taxes by reducing revenue, hence raises the deficit. This causes the growing of consumption that results from spending of money by taxpayers that borrow abroad. These provide the support to twin deficit hypothesis where positive linkage among fiscal deficit and CA deficit will take place which fulfil Keynesian view (Chinn \& Ito, 2007; Baharumshah et al., 2009; Forte \& Magazzino, 2013; Trachanas \& Katrakilidis, 2013; Gossé \& Serranito, 2014; Coban \& Balikcioglu, 2016; Afonso \& Opoku, 2018).

Debt is defined as sum of money borrowed by one party from another. Government debt is in contrast to the annual government budget deficit, where it is a flow variable that equal to the difference between government revenue and expenditure in a year (Forte \& Magazzino, 2013). After global financial turmoil, public debt has been towering to a rather high degree (Reinhart \& Rogoff, 
INTERNATIONAL JOURNAL OF ACADEMIC RESEARCH IN BUSINESS AND SOCIAL SCIENCES Vol. 9, No. 7, July, 2019, E-ISSN: 2222-6990 @ 2019 HRMARS

2010). Accumulation of public debt every year will induce the rising of fiscal deficit. Besides, the increases of fiscal deficit also leads by the adding of interest on debt every year. As growing yearly, previous debt amount, debt interest, and current adding newly debt will definitely expand debts to higher level. High debt level will lead to effect on fiscal deficit.

Constant and huge CA surplus is a new phenomenon in ASEAN countries. The CA data reveals that CA deficits have decreased in Malaysia, Thailand, Philippines, and Singapore, where these countries are with large public indebtedness. The driver of this phenomenon may cause by the downshift in domestic output and demand (Sulikova \& Tykhonenko, 2017). Hence, selected ASEAN countries, Indonesia, Malaysia, Philippines, Singapore, Thailand, and Vietnam are chosen to be examined. CA of Indonesia experiences continuous decrease since 2000 until demonstrates deficit recently. According to Guinigundo (2010), 2008 subprime mortgage crisis had induced Asian stock markets to decline, where Indonesia's bond spreads are the largest among emerging Asian economies. Whereas, Malaysia gains a peak CA surplus at $16.52 \%$ of GDP in 2008. This is because Malaysia responds to crisis by implementing two stimulus packages with direct cash injections (Athukorala, 2010; Sangakala, Ahmed, \& Pahi, 2016). In 2008, Philippines exhibits a sharp decline in CA, induced by negative result of exports that causing by Philippine Peso depreciation and also weak external demand. Furthermore, the devaluation of peso and the surge in imports of rice and oil lead to a drop in export growth and a rise in import costs too.

Next, Singapore regularly reveals current account surpluses. Singapore has the ability to initiate fiscal surplus and successful in developing that attracts large capital inflows. Nevertheless, IMF suggests Singapore to minify its huge CA surplus by increasing public spending on social services and infrastructure. In latter half of 2014, CA of Thailand has improved to surplus after the relieving of political uncertainty. Nevertheless, Thai economy has faced some unfavourable factors in 2016, such as weak exports, internal doubt, global political dynamic, and volatile global financial markets. Yet, the tourism sector has refilling its important role as development driver to strengthen the economy. On the other hand, after 2008 crisis, CAB of Vietnam continues to rise until surplus. This is reflecting by the acceleration of industrial manufacturing production. Besides, Vietnam also signs some free trade agreements with key district to expand geographical scope of its market.

Figure 1. Current Account Balance of 6 ASEAN Countries, 1990-2016

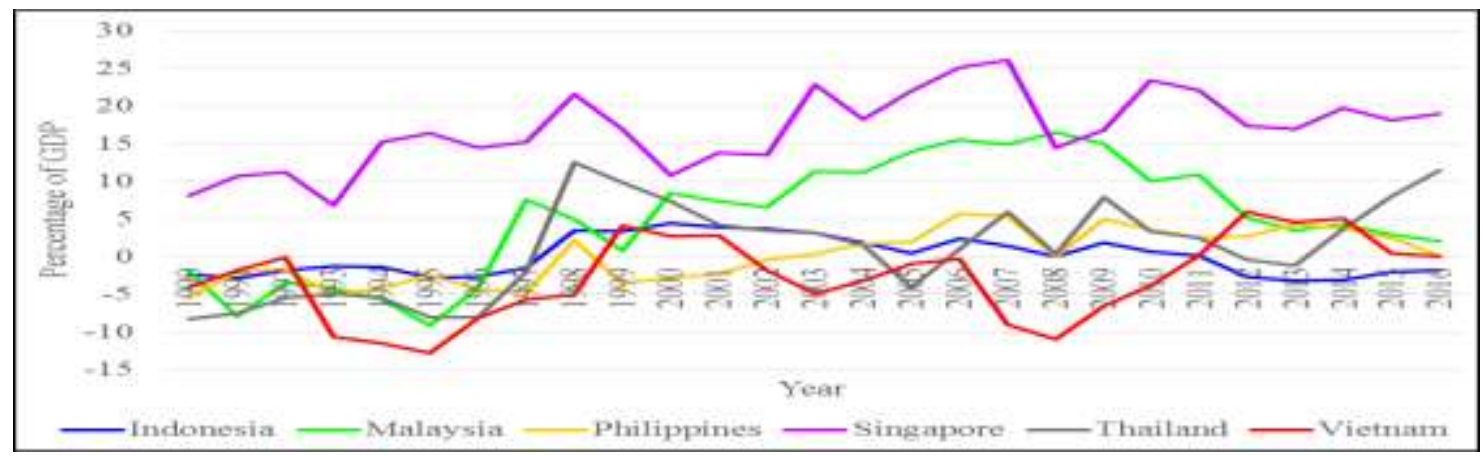

Source: International Monetary Fund, World Economic Outlook Database (April, 2017). 
One of the tools used to manage the current account imbalance is the fiscal policy. There are a huge number of empirical research studies focus on the relationship between twin deficits in developed nations, such as US and Euro countries, for example the empirical studies by Trachanas and Katrakilidis (2013); Gossé and Serranito (2014); Bollano and Ibrahimaj (2015); Coban and Balikcioglu (2016); Afonso and Opoku (2018). However, with the development of modern macroeconomics over the past half century, researchers have neglected to review debt issues as well. Debt is described as two-edged sword, where high and uprising debt has become an origin of certified concern (Cecchetti, Mohanty, \& Zampolli, 2011). When using wisely, it will help to enhance welfare. Oppositely, using in excess, it will cause disaster. The accumulated sum of debt implicates the risk. As debt levels raise, borrowers' repayment capability is becoming more sensitive to falling revenue and sales, even rising of interest rates (Cecchetti et al., 2011). The higher the degree of debt, the larger the narrow in size of economy shock. Therefore, in this study, public debt is adopted to investigate the relationship between twin deficits in ASEAN-6 countries. This is in order to fill the empirical gap between twin deficits and debts in ASEAN region, whereby previous studies are mostly concentrated on twin deficits in developed nations.

Furthermore, debts is important to include in model, which also done by Debelle and Faruqee (1996), Alam and Taib (2013), and Sǔliková and Tykhonenko (2017). Debts and fiscal deficit has significant relationship, where the size and component of debts will influence fiscal deficit. Serving large amounts of debts will increase government spending and channels to borrowing. Besides, it becomes a major concern is that widening of budget deficit in countries is requiring more fund to finance. Nevertheless, in the long run, excessive reliance on foreign financing will lead to increase in debt sustainability and interest payments, resulting a large debt for future generations (Girma, 2018). Thus, the accumulation of large public debt brings the shrinking in budget deficits and also the extensive of CA deficits. In conjunction, the main objective of this study is to examine the relationship between twin deficits and debts.

\section{Literature Review}

Ganchev, Stavrova, and Tsenkov (2012) reviewed twin deficit hypothesis is that fiscal deficit is positively significant to current account deficit, where it becomes guideline for fiscal policy construction. Chinn and Ito (2007) described there is significantly positive linkage among CA and government budget balance. When $1 \%$ accelerate in budget balance, will lead the CAB to increase by $0.15 \%$. Besides, Baharumshah et al. (2009) also proposed budget deficit performs significantly in determining the CA deficit in Malaysia, Philippines, and Thailand. Furthermore, Makrevska-Disovska and Trpkova-Nestorovska (2016) analysed twin balances relationship in Macedonia. They summarized budget balance is significant to CA with positive relation, where $1 \%$ of GDP rises in budget balance leads GDP in CA grows by $0.28 \%$. However, more recently the empirical studies on twin deficits give mixed results. There is a study on 18 OECD countries by Afonso and Opoku (2018) concluded significant long run relationship within FB and CAB. Nevertheless, Girma (2018) found that there even appear of twin divergence phenomenon in Ethiopia, where the long run relationship between $C A B$ and FB is negative and statistically significant. 
Public debt (PD) and fiscal deficit are highly correlated, where the magnitude and element of public debt will cause the fiscal deficit to occur. Debelle and Faruqee (1996) studied effect of fiscal policy on CA in 55 high and low debts countries. They found that in low PD countries, effect of fiscal surplus on CA is significantly positive. Whereas, in high PD countries, the effect is close to zero, consistent with idea that high public debt countries are "more Ricardian". Next, Nickel and Tudyka (2014) studied impact of fiscal stimulus at distinct level of government debt of 17 European nations. Findings indicate twin deficits situation appears at low debt levels, while twin divergence demonstrates during high debt levels. In addition, Sǔliková and Tykhonenko (2017) examined twin deficits hypothesis with public debt of European countries too. Their findings denote twin divergence phenomenon when public debt is less than $40.2 \%$ and more than $96.6 \%$, which is negative significant relationship within $\mathrm{FB}$ and $\mathrm{CAB}$. However, there is existence of twin deficits when public debt is in gap between $40.2 \%$ and $96.65 \%$.

\section{Data and Methodology}

The research countries are selected 6 ASEAN countries from 1990 to 2016 annually with balanced panel data approach. The dependent variable is current account balance (CAB); independent variables are fiscal balance (FB), public debt (PD), real GDP (RGDP), real effective exchange rate (REER), age dependency ratios for old (ADRO), and age dependency ratio for young (ADRY). Data is retrieved from IMF, World Economic Outlook Database and World Bank, World Development Indicator. PD is defined as debt owned by government foreign lenders. According to Barro (1979), public debt is cleared as the aggregate of present value of government spending and the initial debt level; RGDP is the cost of all services and goods generates by an economy in a year; REER is the measure of a currency value in contrary to a weighted average of some foreign currencies in relation to an index of costs; ADRO is ratio for people older than 64 to percentage of working-age population; $A D R Y$ is ratio for young aged under 15 to percentage of working-age population.

The balanced panel model of this study is expressed with logarithm and presented as follow.

$$
L C A B_{i t}=\alpha+\beta_{1} L F B_{i t}+\beta_{2} L P D_{i t}+\beta_{3} L R G D P_{i t}+\beta_{4} L R E E R_{i t}+\beta_{5} L A D R O_{i t}+\beta_{6} L A D R Y_{i t}+\varepsilon_{i t}
$$
Panel Unit Root Tests

Unit root test is adopted to measure the stationary of a procedure that alter with time. Stationary test is necessary in investigating the variables to discover their effectiveness of norm hypothesis for the asymptomatic analysis. In order to have a stationary process, others of this identity equation that lies among the particular absolute value is required to distinguish the amount of units according to the process. Levin, Lin, and Chu (2002) and Im, Pesaran, and Shin (2003) unit root tests are adopted.

\section{Panel Cointegration Tests}

Cointegration test is primarily applied to investigate the long run equilibrium relationship between variables. Cointegrating test is a signification of feasibilities to serve as a cointegrating vector whereby the coefficient can be straightly explained as long-term equilibrium. In Pedroni (1999) test, cointegrated of variables are determined by denominating number of significant or insignificant variables. Pedroni (1999) and Kao (1999) are used in this study.

Pooled Mean Group (PMG) Estimation 
INTERNATIONAL JOURNAL OF ACADEMIC RESEARCH IN BUSINESS AND SOCIAL SCIENCES Vol. 9, No. 7, July, 2019, E-ISSN: 2222-6990 @ 2019 HRMARS

PMG adopted to examine non-stationary dynamic panels, where parameters are heterogeneous across units (Pesaran, Shin, \& Smith, 1999; Matarid, Sobh, \& Ahmed, 2018). PMG emphasizes the identical of long run coefficients, whereby crossing the countries, short run coefficient and error variances allow to vary easily across groups.

\section{Empirical Findings}

\section{Panel Unit Root Tests}

The null hypothesis for Levin et al. (2002) and Im et al. (2003) are unit root exists. In first difference, I(1), variables are smaller than significant value, thus reject null hypothesis (refer Table 1). Therefore, by concluding both unit root tests, all variables are stationary at $/(1)$ with no unit root exists.

Table 1. Levin, Lin, and Chu (LLC) and Im, Pesaran, and Shin (IPS) Panel Unit Root Tests Results

\begin{tabular}{|c|c|c|c|c|}
\hline \multicolumn{5}{|c|}{ Test Statistics } \\
\hline & LLC & IPS & LLC & IPS \\
\hline \multicolumn{3}{|c|}{ Individual Intercept } & \multicolumn{2}{|c|}{ Individual Intercept and Trend } \\
\hline \multicolumn{5}{|c|}{ Level } \\
\hline LCAB & $-1.1139(0.1327)$ & $-1.2897(0.0986)^{*}$ & $-1.0116(0.1559)$ & $-1.7570(0.0395)^{*}$ \\
\hline LFB & $-2.6421(0.0041)^{*}$ & $-2.4271(0.0076)^{*}$ & $-3.3286(0.0004) *$ & $-2.3810(0.0086)^{*}$ \\
\hline LPD & $-15.3981(0.0000)^{*}$ & $-8.3489(0.0000)^{*}$ & $-9.6784(0.0000)^{*}$ & $-6.4176(0.0000)^{*}$ \\
\hline LRGDP & $-1.0748(0.1412)$ & $2.4331(0.9925)$ & $-1.6223(0.0524)^{*}$ & $-1.7144(0.0432) *$ \\
\hline LREER & $-1.5347(0.0624)^{*}$ & $-0.1760(0.4301)$ & $-0.1504(0.4402)$ & $0.4449(0.6718)$ \\
\hline LADRO & $1.3948(0.9185)$ & $4.1973(1.0000)$ & $-0.8572(0.1957)$ & $-1.3728(0.0849)^{*}$ \\
\hline LADRY & $-4.0286(0.0000)^{*}$ & $-0.2184(0.4136)$ & $-3.5134(0.0002)^{*}$ & $-1.7592(0.0393) *$ \\
\hline \multicolumn{5}{|c|}{ First Difference } \\
\hline$\triangle \mathrm{LCAB}$ & $-9.0204(0.0000)^{*}$ & $-10.8101(0.0000)^{*}$ & $-3.6017(0.0002) *$ & $-9.1555(0.0000)^{*}$ \\
\hline$\Delta \mathrm{LFB}$ & $-10.6245(0.0000)^{*}$ & $-10.7976(0.0000) *$ & $-7.9994(0.0000)^{*}$ & $-8.7068(0.0000)^{*}$ \\
\hline$\Delta \mathrm{LPD}$ & $-8.1318(0.0000)^{*}$ & $-8.1029(0.0000) *$ & $-5.1504(0.0000)^{*}$ & $-6.1962(0.0000)^{*}$ \\
\hline$\Delta \mathrm{LRGDP}$ & $-6.1989(0.0000)^{*}$ & $-5.5605(0.0000) *$ & $-5.2280(0.0000)^{*}$ & $-5.8448(0.0000) *$ \\
\hline$\Delta$ LREER & $-7.8839(0.0000)^{*}$ & $-7.2534(0.0000)^{*}$ & $-6.6959(0.0000)^{*}$ & $-5.7540(0.0000)^{*}$ \\
\hline$\triangle \mathrm{LADRO}$ & $0.4916(0.6885)$ & $-2.0754(0.0190)^{*}$ & $1.5322(0.9373)$ & $0.0132(0.5052)$ \\
\hline$\triangle \mathrm{LADRY}$ & $-2.2868(0.0111)^{*}$ & $-1.8572(0.0316)^{*}$ & $2.0420(0.9794)$ & $2.6518(0.9960)$ \\
\hline
\end{tabular}

Note. LLC indicated Levin et al. (2002) and IPS indicated Im et al. (2003) panel unit root and stationary tests. The LLC and IPS examine the null hypothesis of non-stationary of variables. The parenthesized values are the probability of rejection. Asterisks $(*)$ indicates statistically significant at 10 percent level.

Panel Cointegartion Tests

In both Pedroni (1999) and Kao (1999) cointegration tests, the null hypothesis are no cointegration (no long run). The result in Pedroni test shows that there are four out of seven majority statistics have sufficient evidence on rejecting the null hypothesis (refer Table 2). On the other hand, the probability value in Kao test is smaller than significant level, which indicates to reject null hypothesis too. In conclude, all variables are cointegrated in long run.

Table 2. Panel Cointegration Tests Results 
INTERNATIONAL JOURNAL OF ACADEMIC RESEARCH IN BUSINESS AND SOCIAL SCIENCES

Vol. 9, No. 7, July, 2019, E-ISSN: 2222-6990 @ 2019 HRMARS

A: Pedroni Residual Cointegration Test

Panel cointegration statistics (within-dimension)

Panel $v$-statistics

$0.2601(0.3974)$

Panel rho-statistics

$0.9497(0.8289)$

Panel PP-statistics

$-1.5160(0.0648)^{*}$

Panel ADF-statistics

$-4.7201(0.0000)^{*}$

Group mean panel cointegration statistics (between-dimension)

Group rho-statistics

$1.3191(0.9064)$

Group PP-statistics

$-5.5882(0.0000)^{*}$

Group ADF-statistics

$-5.3619(0.0000)^{*}$

\section{B. Kao Residual cointegration test}

ADF

$-3.1856(0.0007)^{*}$

Note. The number of lag truncations used in the calculation of the seven Pedroni statistics is 4 while Kao ADF statistic is 6 . The parenthesized values are the probability of rejection. Asterisks $(*)$ indicates statistically significant at 10 percent level.

\section{Pooled Mean Group (PMG) Estimation}

According to Bangake and Eggoh (2012), in order to assess the null hypothesis of homogeneity, Hausman test is performed to distinguish between mean group (MG) and PMG estimators. Based on Hausman test result in Table 3, p-value indicates that null hypothesis is failed to reject. Therefore, in this study, supporting the employment of PMG estimator. PMG highlights the adjustment between short and long run that involving both pooling and averaging. The result of PMG estimation demonstrates that LPD is affecting relationship of LFB and LCAB, where both balances show a positive and statistically significant relationship. This finding is coherent with the traditional twin deficits hypothesis and also fulfil the Keynesian theory, where government spending is driving force to aggregate demand. When taxable income reduced, causes rising in budget deficit, as government spends more to meet the demand. This leads government expenses to exceed revenue. This reflects the domestic absorption.

Table 3. Hausman Test and PMG Estimation Results

\begin{tabular}{ll}
\hline & Panel Group \\
LFB & $0.2559(0.0345)^{*}$ \\
LRGDP & $0.3954(0.0000)^{*}$ \\
LREER & $-1.0781(0.0000)^{*}$ \\
LADRO & $-0.1818(0.6942)$ \\
LADRY & $-0.5866(0.0604)^{*}$ \\
LPD & $-0.1144(0.3052)$ \\
\hline Hausman Test & \\
Chi-square statistics & 12.3500 \\
$p$-value & 0.0545 \\
\hline
\end{tabular}

Note. Asterisks $(*)$ indicates statistically significant at 10 percent level. If $p$-value greater than $5 \%(0.05)$, do not reject $H_{0}$.

\section{Conclusion}


The objective of this study is to determine the relationship between twin deficits and debts in the selected 6 ASEAN countries from 1990 to 2016 annually. The dependent variable is CAB; independent variables are $F B, P D, R G D P, R E E R, A D R O$, and $A D R Y$. Panel unit root tests and panel cointegration tests are adopted and also PMG estimation. The major findings show that the presence of public debt will affect $F B$ and $C A B$ to demonstrate a positive and statistically significant relationship. The relation is either performing as twin deficits or twin surpluses. Kueh, Liew, Yong, and Abdullah (2016) agreed that public debt has becomes an important global issue, where a country tends to seek alternatives from overseas on borrowing to mitigate any serious negative impacts caused by economic shocks.

From a policy perspective, the economic uncertainty in this contemporary era has brought in the case of unavoidable debt accumulation. Together with the findings of this study suggest that handling optimal debt is very important so as to overcome the unbalances of fiscal account and current account. Therefore, public debt should be paid with highly concern of policymakers in the countries to overcome the deficits issues. Kueh, Liew, and Yong (2017) mentioned that it is a great task in controlling the debt at optimal level, as different type of debts and different level of debts will behave differently to current account and fiscal account. In spite of that, the well-being of people must also be included during debt structure (Kueh et al., 2016). Fiscal rules are useful in limiting government spending, income, unexpected income, budget balance or even debt, such as the fiscal consolidation. According to Margit (2012), during the fiscal consolidation, if the fiscal adjustment is refer to expenditure rather than tax drive, the debt will be stabilized and the stability is long-lasting. Fiscal consolidation can be introduced to state-level governments in order to work together with central governments in the effort of debt stabilization. Hence, the public debt of country can be controlled and maintained, so as to ensure the sustainability of fiscal balance and current account balance of a country in long term.

According to traditional twin deficits hypothesis and also the Keynesian theory, they suggested that current account deficits and fiscal deficits have positive relationship among each other. As referring to this research, the major findings are significant to the theoretical contribution, where there is positive linkage between twin balances with the presence of public debt. In spite, public debt has becomes a highly concerned global issue and it also plays an important role in affecting the relationship between twin balances. Hence, it is a huge challenge to maintain optimal debt level, in order to overcome the twin deficits issue.

\section{References}

Afonso, A., \& Opoku, P. K. (2018). The relationship between fiscal and current account imbalances in OECD economies. REM Working Paper, 061-2018.

Alam, N., \& Taib, F. M. (2013). An investigation of the relationship of external public debt with budget deficit, current account deficit, and exchange rate depreciation in debt trap and non-debt trap countries. European Scientific Journal, 9(22), 144-158.

Athukorala, P. C. (2010). Malaysian economy in three crises (The ANU Working Paper No. 2010/12). Canberra, Australia: The Australian National University. 
INTERNATIONAL JOURNAL OF ACADEMIC RESEARCH IN BUSINESS AND SOCIAL SCIENCES

Vol. 9, No. 7, July, 2019, E-ISSN: 2222-6990 @ 2019 HRMARS

Baharumshah, A. Z., Ismail, H., \& Lau, E. (2009). Twin deficits hypothesis and capital mobility: The ASEAN-5 perspective. Jurnal Pengurusan, 29, 15-32.

Bangake, C., \& Eggoh, J. C. (2012). Pooled mean group estimation on international capital mobility in African countries. Research in Economics, 66(1), 7-17.

Barro, R. J. (1979). On the determination of the public debt. Journal of Political Economy, 87(5), 940971.

Bollano, J., \& Ibrahimaj, D. (2015). Current account determinants in Central Eastern European countries (Working Paper No. 22-2015). The Graduate Institute of International and Development Studies.

Cecchetti, S. G., Mohanty, M. S., \& Zampolli, F. (2011). Achieving growth amid fiscal imbalances: The real effects of debt. In Economic Symposium Conference Proceedings (Vol. 352, pp. 145-196). Federal Reserve Bank of Kansas City.

Chinn, M. D., \& Ito, H. (2007). Current account balances, financial development and institutions: Assaying the world "saving glut". Journal of International Money and Finance, 26(4), 546-569.

Coban, H., \& Balikcioglu, E. (2016). Triple deficit or twin divergence: A dynamic panel analysis. The International Journal of Economic and Social Research, 12(1), 271-280.

Debelle, G., \& Faruqee, H. (1996). What determines the current account? A cross-sectional and panel approach (IMF Working Paper No. 58). US: International Monetary Fund (IMF).

Forte, F., \& Magazzino, C. (2013). Twin deficits in the European countries. International Advances in Economic Research, 19(3), 289-310.

Ganchev, G. T., Stavrova, E., \& Tsenkov, V. (2012). Testing the twin deficit hypothesis: The case of Central and Eastern European countries. International Journal of Contemporary Economics and Administrative Sciences, 2(1), 1-21.

Girma, M. (2018). Determinant of current account balance of Ethiopia economy: An autoregressive distributed lag approach. (Doctoral dissertation). St. Mary's University, Mexico.

Gossé, J. B., \& Serranito, F. (2014). Long-run determinants of current accounts in OECD countries: Lessons for intra-European imbalances. Economic Modelling, 38, 451-462.

Guinigundo, D. C. (2010). The impact of the global financial crisis on the Philippine financial system: An assessment. BIS Papers, (54), 317-342.

Im, K. S., Pesaran, M. H., \& Shin, Y. (2003). Testing for unit roots in heterogeneous panels. Journal of Econometrics, 115(1), 53-74.

Kao, C. (1999). Spurious regression and residual-based tests for cointegration in panel data. Journal of Econometrics, 90(1), 1-44.

Kueh, J., Liew, V. K. S., Yong, S. W., \& Abdullah, M. A. (2016). Estimation of public debt threshold of Malaysia. In International Conference on Contemporary Economic Issues 2016 (pp. 17-24). Bali, Indonesia: School of Social Sciences, USM.

Kueh, J., Liew, V. K. S., \& Yong, S. W. (2017). Modeling Malaysia Debt Threshold: Debt Composition Perspective. International Journal of Business and Society, 18(S4), 800-807.

Levin, A., Lin, C. F., \& Chu, C. S. J. (2002). Unit root tests in panel data: Asymptotic and finite-sample properties. Journal of Econometrics, 108(1), 1-24.

Matarid, N. M., Sobh, O. S., \& Ahmed, U. (2018). The Impact of Organizational Justice and Demographics on Faculty Retention in Bahrain. Le travail humain, (3). 
Makrevska-disovska, E., \& Trpkova-Nestorovska, M. (2016). Factors affecting current account in the Republic of Macedonia. CEA Journal of Economics, 10(2), 45-56.

Margit, M. (2012). Fiscal consolidation: What factors determine the success of consolidation efforts? OECD Journal: Economic Studies, 2012(1), 123-149.

Nickel, C., \& Tudyka, A. (2014). Fiscal stimulus in times of high debt: Reconsidering multipliers and twin deficits. Journal of Money, Credit and Banking, 46(7), 1313-1344.

Pedroni, P. (1999). Critical values for cointegration tests in heterogeneous panels with multiple regressors. Oxford Bulletin of Economics and Statistics, 61(S1), 653-670.

Pesaran, M. H., Shin, Y., \& Smith, R. P. (1999). Pooled mean group estimation of dynamic heterogeneous panels. Journal of the American Statistical Association, 94(446), 621-634.

Reinhart, C. M., \& Rogoff, K. S. (2010). Growth in a time of debt. American Economic Review, 100(2), 573-578.

Sangakala, M., Ahmed, U., \& Pahi, M. H. (2016). Empirical investigating on the role of supervisor support, job clarity, employee training and performance appraisal in addressing job satisfaction of nurses. International Business Management, 10(23), 5481-5486.

Sulikova, V., \& Tykhonenko, A. (2017). The impact of public debt on the twin imbalances in Europe: A threshold model. Economic Annals, 62(213), 27-44.

Trachanas, E., \& Katrakilidis, C. (2013). The dynamic linkages of fiscal and current account deficits: New evidence from five highly indebted European countries accounting for regime shifts and asymmetries. Economic Modelling, 31, 502-510.

\section{Correspondence Author}

Jerome Kueh

Faculty of Economics and Business, Universiti Malaysia Sarawak, 94300 Kota Samarahan, Sarawak, Malaysia. Email: kshjerome@unimas.my 